\title{
How to Manage French Thermalism Specificities?
}

\author{
Naïade Anido Freire ${ }^{1}$ \\ ${ }^{1}$ School of Management, ISC Paris, Paris, France \\ Correspondence: Naïade Anido Freire, School of Management, ISC Paris, 22, Bd. du Fort de Vaux, 75017, Paris, \\ France. Tel: 33-1-4053-9999. E-mail: n.freire@wanadoo.fr
}

Received: November 24, 2012

Accepted: December 17, 2012

Online Published: January 25, 2013

doi:10.5539/ibr.v6n3p29

URL: http://dx.doi.org/10.5539/ibr.v6n3p29

\begin{abstract}
Although each curist (hydrothermal patient) spends an average of $500 €$, for 18 days of intensive cure (treatment), Thermalism is in France one billion $€$ of turnover. Famous since ancient Greco-Roman, treatments through Thermalism attracts today some 500000 followers. Presently, French Social Security takes in charge an important rate $(65 \%)$ of the expenditure incurred by the medically prescribed thermalism treatments, which certainly has encouraged its development. Despite being regarded by some people as old-fashioned and whose target consumers are elderly, thermalism attract each year 17\% new thermal curists, many of whom are young adults. Teens and children also benefit from new technologies and therapeutic thermalism. The hydrothermal patients spend annually around one billion $€$ in French Thermalism: a financial manna that France is willing to protect at all costs, especially in the current context of economic and financial crisis and economic, labor and thermal globalization.
\end{abstract}

Keywords: thermalism, thermal cure, French thermal springs, management of thermalism, thermalism turnover, Social Security, tourism, SPA

\section{Introduction}

In France, the thermalism has a long historical tradition and is well established in the thermal cities and thermal regions (Duhot \& Fontan, 1963; Jamot, 1998). Famous from Greco-Roman antiquity, the millenarian thermal baths (Jaltel, 2003) evolved constantly and French thermal cures presently attract around 500000 followers.

The French Thermalism is performed in 118 Thermal Centers (ThC). Although each curist spends an average of $500 €$, French Thermalism represents one billion euros of turnover and in this way, this economic sector constitutes a real financial manna. French thermalism contributed to the creation and maintenance of 100000 direct, indirect and induced jobs, to the economic and tourism development, and thus, to the reputation of various thermal regions (Anido Freire, 2012a).

Considered by some people as old-fashioned and whose target consumer is the elderly, however thermal cures attract every year $17 \%$ of new thermal curists, many of whom are young adults. Teens and children patients also benefit from the new techniques and therapies of thermal waters (Armand et al., 1991; Jaltel, 2011).

The sedative and curative powers of thermal treatments, that were formerly ignored or rejected/denied by doctors, are presently recognized not only by thermal doctors but also by generalists, specialists and surgeons, which note the improvement that such cures bring to their patients.

Moreover, since 1947 the French Social Security (SS) recognizes the validity of thermalism treatments and agrees to take in charge a high percentage $(65 \%)$ of the cost of thermal treatments, prescribed by physicians to their patients. Of course, the curist assumes the costs of accommodation and restaurant.

The aim of this paper is to present the specificities of French Thermalism that differentiate it (Weisz, 2002) from other European thermal practices (Germany, Italy, Spain, Romania) and from the Anglo-Saxon thermal waters (UK, U.S.) or SPA activities. All stakeholders of the French Thermalism, including ministerial authorities and French SS, are unanimous on the need to preserve and develop these medical thermal treatments in the future.

Having reviewed the Thermalism terminology (section 2) and different types of cures that can be made with natural thermal springs we present the French Thermalism sector (section 3), the thermal cities, the thermalism evolution (section 4) and positive effects on local and regional finances (section 5). These economic effects are the result of a appropriate management to this sector (section 6), which is further supported by the network of 
tourism stakeholders (section 7). After a general discussion of the French thermalism sector and a SWOT analysis (section 8), we propose a series of possible strategic guidelines (section 9).

The French Thermalism sector emerges strengthened from the economic and financial crisis, and fulfill all the conditions (economic, managerial, communication and marketing strategies) to continue to be competitive in the market for European thermal waters and to evolve positively in the future (section 10).

\section{Rectifying and Clarifying the Terminology}

The Thermalism can be considered as an activity in the sector of Health Tourism (Direction du Tourisme, 2010; Anido Freire, 2012b).

Thermal therapy, which is also known in France under the name crenotherapy (Greek krênê = water source), designates therapeutic techniques performed with the use of thermal or hydromineral waters (springs), and other materials containing thermal mineralizing principles and trace elements exerting its healing effects on the human body. Since the early nineteenth century, arise the terms "thermal cure" or simply "cure" - from a semantic extension and absolute building, i.e. without explicit its complement - and "curist", to describe the treatment performed in a thermal center (station/resort) and the person doing it.

We therefore propose the following definitions of Thermalism and Thermal Tourism.

Thermalism is the set of activities concerning the organization, the adaptation and constant renewal of Thermal Centers (ThC), specially constructed for therapeutic uses, as well as to land management and respect for the environment around them.

The ThC professionally exploit the virtues of the thermal, mineral and natural waters and the subsoil, they manage the health personnel performing cures and the hotel services staff, as well as the attendance and monitoring of curists.

In Europe, Thermal Tourism (TT) gathers all the tourist activities centered around the existence of one or more mineral thermal springs and $\mathrm{ThC}$, located in a city or a region of a given country, and whose fame is the result of its undisputed beneficial actions on health and / or wellbeing of the human being, as known since Roman times.

It is worth noting three facts: first, that in France Tourism, and therefore Thermal Tourism, is subordinated to the Ministry of the Economy, Finance and Industry, through the Department of Tourism (Jacob, 2010), which integrates the General Directorate for Competitiveness, Industry and Services (DGCIS).

Second, due to the various agreements signed with the Ministry of Health (Fenina, Le Garrec \& Koubi, 2010a) and the National Social Security Fund, the Thermalism is also subordinated to the Ministry of Health and its activities appears in the statistics of this Ministry.

Third, in France (French activities nomenclature $=\mathrm{NAF}$ ) it is established a clear and net differentiation between:

- The Thermalism or Crenotherapy (NAF $93.0 \mathrm{~K}$ and after 2008, NAF $96.04 \mathrm{Z}$ ) includes all medical and paramedical treatments, internal (thermal water intake) or external (showers, baths, massages), using only the thermal waters and its derivatives (mud, peloid, loam, gases) in various therapeutic techniques. It is a therapy in which the change of environment, of climate and lifestyle routine, create ideal conditions (calmness and relaxing) to satisfy the curist's expectations (European proposal, 2010a).

- The Thalassotherapy (from the Greek Thalassa = sea) uses the beneficial effects of sea or ocean water and other elements of the marine environment (sand, salt, algae), under medical supervision and with preventive and / or curative goals.

- The SPA (word or acronym that arises in English-speaking countries around the 1980s), which is used in beauty salons, aesthetic and fitness centers, often urban and high-end (Delomenie, 2000). In fact, SPA is a "beauty care" ("soins de Beauté" NAF 93.0 E and since 2008, NAF 96.02 B) and not a "medical or paramedical" treatment as they are made in the ThC, despite the use of some similar materials (bathrooms with whirlpools in bathtubs or jacuzzis, water jets, massage, etc.). SPA owners began to use improperly the term "SPA centers", even though many of them are installed in city centers, in hotels and camping, to create consumer confusion by offering a service that uses as raw material the tap water rather than naturally thermal water. We believe that the SPA should be called "aqualudism".

\section{Specificities of French Thermalism}

(a) Thermalism in France (Weisz, 2002; Roques, 2003; Syndicat National des Médecins Thermaux [SNMTh], 2007) is a Medical Thermalism (MTh) and contrary to what happens in most of the other countries which is a free thermalism (in self-service and "a la carte"), the cure must: 
- necessarily respect duration of 3 successive weeks, with 18 days of cure required to be approved by the ThC and the SS (Conseil National des Exploitants Thermaux [CNETh], 2010c);

- have the same duration for all curists, regardless of the pathologies they have;

- be prescribed by the "referring physician" (equivalent to the former "family doctor") during a medical visit: without this prior prescription, the ThC will not accept to perform the cures and the SS will reject to pay $65 \%$ of the total amount of the cure (CNETh, 2010c), the remaining 35\% being on charge of curists;

- receive the "agreement of the SS" ("entente préalable SS");

- be carried out in one of the establishments listed on the official list of the SS and that are the only ones authorized to dispense thermal treatments;

- be controlled by doctors specializing in thermal hydrotherapy (SNMTh, 2007);

- be performed by a professional, specialized in thermal techniques or hydrotherapy;

- be associated with complementary therapies delivered by physiotherapists ("kinésithérapeute") graduated by an official institution, and specialized in Rheumatology, Phlebology, etc.

- be associated with optional treatments with local thermal mud and peloids having proven healing powers;

- be supplemented by the daily practice of physiotherapy, adequate to the specific pathology and practiced in local thermal water pool.

(b) Although done in a collective place (ThC), to which come curists with similar health problems or identical pathologies, the French thermal cure is practiced individually and personalized.

The ThC makes available to curists the physical infrastructures and the adequate professional staff to realize the treatments and a pleasant and appropriate environment for their wellness.

On arrival at ThC, each curist receives a detailed planning of his cure plan respecting the directives established by the hydrotherapist doctor who examined him: type and number of treatments, swimming pool, bathtub and temperature of the thermal water, cabin number, name of the masseur or physiotherapist, duration of each stage, rest time lapses, etc.

(c) In addition to a complete thermal cure, the curist receives:

- a parallel health education with practical recommendations to respect during the interval between two periods of cures: normally the curist is advised to make an annual thermal cure;

- a culinary education aiming the advantage of the complementarities of good nutrition for good health.

(d) The hydrothermal doctor makes an initial control (weight, measurements, interrogation, cardiovascular, venous, respiratory, skin, etc.), other in the middle and the last one at the end of the cure and sends a report to the referring physician who regularly follows the patient.

(e) For greater benefits, ThC propose the possibility of associating the thermal cure with a dietary cure (CNETh, 2008) and a physical / sportive cure (hiking, cycling, other sports).

(f) The ThC play a dual role: they are centers that perform thermal treatments and hotels specialized in thermalism: hotel receptionists plan schedules, the frequency and the chain of sessions (stages of treatment, treatment sessions), from the protocol prescribed by the doctor hydrotherapist.

This managerial practice reflects seriousness and allows control the successful completion of each stage of the treatment.

(g) The buildings of ThC have architectures adapted to the therapeutic purposes, that is, cabins, swimming pools, baths, relaxation rooms and spaces of conviviality (TV, newspapers, coffee, croissants) which favor and encourage dialogue and exchanges between curists.

(h) To comply with the conditions of hygiene, the THC:

- make daily chemical checks of the quality of water, peloids, etc.;

- put, at the service of curists, peignoirs, towels needed for cures (changed several times a day) and plastic overshoes.

(i) The communication techniques of French ThC translate a policy of transparency and deontology: for the curist can check the veracity of the information he is invited to visit the natural thermal water sources and the plant where the $100 \%$ natural, local and organic peloid is prepared and conditioned (environment friendly / 
sustainable development).

(j) Finally, to link the physical to the psychological wellbeing (equilibrium), the $\mathrm{ThC}$ with the Regional Delegation of Tourism, suggested sightseeing and cultural visits, dining, celebrations, including intellectual and intergenerational gatherings.

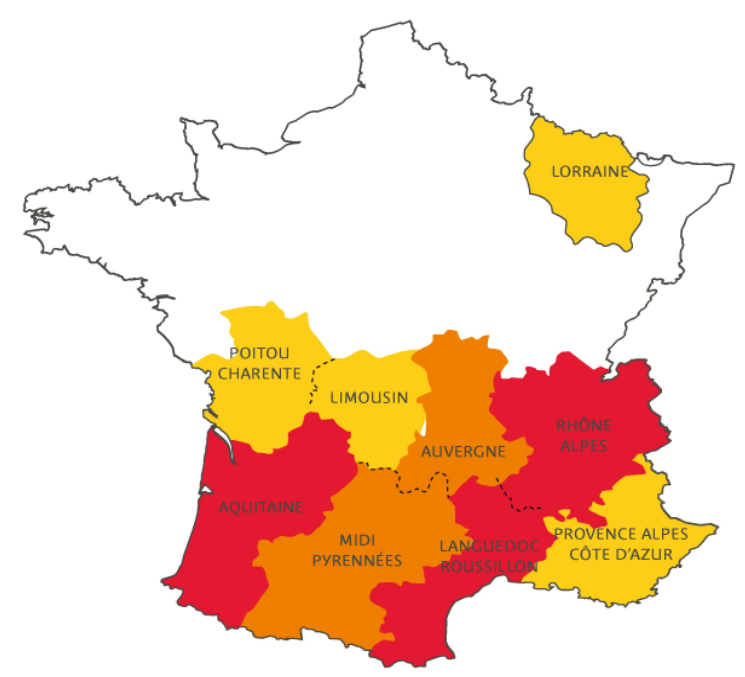

Figure 1. The 9 most important French thermal regions (out of 15)

Description: Aquitaine, Languedoc-Roussillon, Rhône-Alpes; Midi-Pyrénées and Auvergne; Poitou-Charente, Limousin, Provence Alpes Côte d'Azur (PACA) and Lorraine. The first five regions account for $70 \%$ of curists and the 8 located in the south, account for $90 \%$.

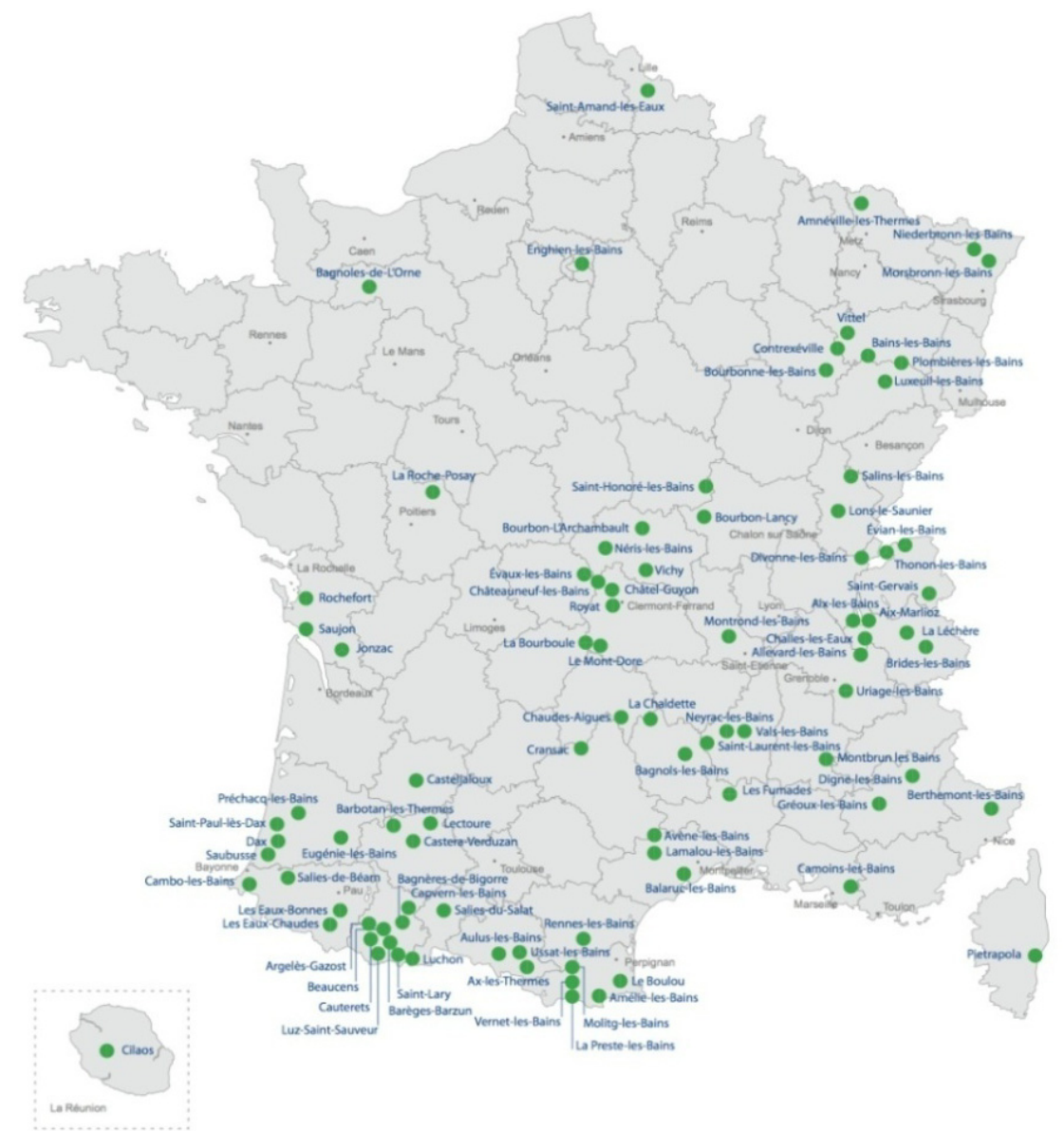

Figure 2. Main French thermal towns (Mosset \& Victor, 2011) 


\section{The Thermalism Sector in France and Its Evolution}

France has 1200 natural mineral water sources, representing 20\% of European thermal water capital. Currently, France has 118 thermal establishments (also called Thermal Centers; Fenina, Le Garrec \& Koubi, 2010b; CNETh, 2010a) receiving annually 500000 curists for whom the French Social Security (SS) takes in charge a percentage of cost of the cure ("cure conventionnée" by the SS). In France, 70\% of thermal waters are concentrated in five regions (CNETh, 2006b, 2010b): Aquitaine, Auvergne, Languedoc-Roussillon, Midi-Pyrénées and Rhône-Alpes (Figures 1 and 2).

Because the cure requires the presence of the curist in the Thermal Center during 18 days of medically supervised thermal treatment, Thermalism in France represents 9 million of treatment days per year and consequently, 9 million days in an essentially collective accommodation (hotel, pension, apartments, campsites, "gîtes").

From the 1950s until 1990, the attendance at the French ThC went from 250000 to 600000 , stabilized between 1990 and 1995 and then declined and re-stabilized around 500000 (Figure 3). In 2010, the demand for thermal cures increased by 3.7\%: curists increased from 487000 (2009) to 505000 (2010).

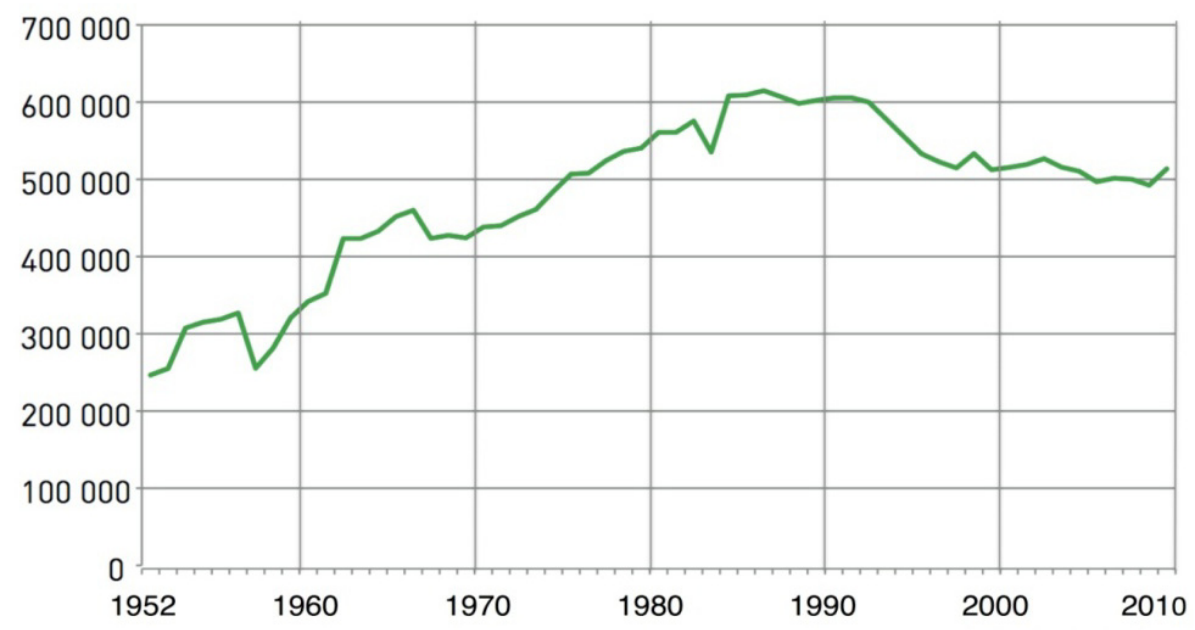

Figure 3. Evolution of the number of French thermal curists

Source: CNETh and Jamot, 1988.

The increase of 3.7\% in 2010 (Figure 3) is due in part to an increase in the number of obese and diabetic in France and around the world and an awareness of physicians towards consumers through advertising campaigns on the need to change eating habits:

- "Eat less salt, less sugar and less fat and move!" ("Mangez moins de sel, moins de sucre, moins gras et bougez!")

- "Eat at least five fruits and vegetables per day" ("Mangez au moins cinq fruits et légumes par jour.")

Similarly, in 2011 the CNETh ("Conseil National des Exploitants Thermaux" = National Council of Thermal Operators) noticed that general practitioners and specialist physicians had advised more easily their patients to make a thermal cure. Perhaps the campaign thermal medicine, effective for a long time / always ("La médecine thermale, efficace pour longtemps") sensitized both doctors and patients. In fact, before, there were only the patients who asked their usual generalist ("médecin référent") to prescribe a thermal cure.

It is indisputable that the bustle of modern life, especially in large cities, the workload and responsibilities, the women's double day (working in the company + housework and parenting), added to the stress resulting from the situation of the global economic, financial and labor crisis and the constant threat of dismissals and unemployment, create ideal conditions to trigger the onset or to aggravate the binomials stress / depression, stress / infarct, bulimia / cachexia or obesity / diabetes already existing.

Concomitant to the prolongation of life, thanks to the constant progress of medicine and drugs, the number of third-and fourth age increases steadily, as well as various pathologies typical of elderly. At the same time, despite numerous campaigns against the use and abuse of tobacco, inveterate smoking did not decline in France, as in other Western societies, and it is noticed that young people start smoking earlier and earlier and that now 
the teenage girls are those that smoke more than teenage boys.

The three main indications of thermal cures in France are: Rheumatology (75\%), Phlebology and respiratory diseases (25\%). Obviously, an inveterate smoking aggravates these latter (CNETh, 2008).

\section{Economic Benefits of Thermalism}

Since 2007, the French thermalism generated 300 million euros/year for thermal cures regardless of the amounts generated by housing curists (Fenina, Le Garrec \& Koubi, 2010a). Considering all these activities, the total volume generated by French thermalism is around one billion euros per year (CNETh, 2010) and has contributed to create 100000 direct, indirect and induced jobs, either permanent or seasonal, of which $50 \%$ are linked to the hotel and restaurant sector (Association Nationale des Maires de Communes Thermales [ANMThC], 2010).

In certain regions of France, the thermalism can represent up to $25 \%$ of global tourism benefits generated by domestic tourism. The collection of the tax for tourist stay (between 0.5 and $1 \%$ of the cost of the overnight stay), that also the curists pay, benefits the local communities and is reused in the development of tourism infrastructure in the region.

The thermal cures are scheduled in the morning from 6:30 to 13:00 to enable curists take advantage of the afternoon to discover the local scenic beauties and the natural, cultural, architectural and gastronomic richness of the city and the region. The thermalism is therefore inseparable from the tourism and the economy of the region because is a source of financial revenue.

\section{Management of French Thermalism}

The French Thermalism has an experience of over 150 years of operation and management. At present, ThC are managed by a director who has a manager experience acquired in a business company or in a ministry. Leaving aside the hotel component that resembles any other hotel management, from the thermal point of view, in each ThC there is a head nurse, graduated in hydrothermal techniques, which manages the thermal staff (physiotherapists, masseurs, therapist technicians). Often, the staff has a versatile training and occupies several positions in the week (a turnover to avoid monotony and fatigue). The management practiced in the ThC is human, vertical (bottom-up and top-down) and horizontal, with frequent daily exchanges between different staff members and between the staff and the manager, with respect to the performance of the devices used as well as with any problems identified by curists. This type of management allows almost immediate reactivity, which translates a competence of quality and safety of the provided services.

In most $\mathrm{ThC}$, the cures are dispensed in the morning, which allows for greater financial returns and also for thermal infrastructures and staff profitability, as well as a higher rate of hotel and thermal occupancy. Moreover, in the morning, after a refreshing sleep, the body is most receptive to such cures and the results are more beneficial. As the cure is effected in a hotel specialized in thermal cures (ThC), curists feel free because they receives treatment "in ambulatory" and, contrary to what happens in a hospital, curists do not feel as an inpatient but has a freedom of movement for the afternoon and night.

But, despite this labor intensity, thermal therapists provide personalized service to curist. Each curist is hosted in a single cabin by the therapist who was officially assigned by the $\mathrm{ThC}$, and receives cures of massage, of mud, a shower of turpentine (rheumatology and phlebology cures) or other substance, or soothing essences (which varies depending on the pathology) and/or a whirlpool.

Only two treatments are carried out in groups:

- the "walking path" ("parcours de marche" for rheumatology and phlebology) made in a thermal pool is performed in mini-groups of 3-6 people controlled by a qualified thermal therapist and

- water gymnastics, also made in thermal pool, in groups of 20 curists, under the responsibility of a qualified teacher.

The concentration of thermal therapies in the morning, allows the ThC to have all the afternoon available for necessary cleaning and repairs (cabins, pools, bathtubs) and for washing and ironing hundreds of bathrobes and towels used daily in the morning cures.

\section{Stakeholders of French Thermalism}

Because the French ThC depends directly on a hot spring, they are intimately linked to a city and a region. The resources of the soil and subsoil and the exploitation of aquifers (distribution networks of thermal waters) depend administratively of municipalities ("mairies"), the County Councils ("Conseils Départementaux") and the Regional Councils ("Conseils Régionaux"). 
These public stakeholders have therefore the right to regularly monitor the technical and therapeutic functioning, and the ethical and financial transparency of ThC. Also, they can give grants to improve the quality of ThC and their environment. For its part, the Ministry of Health and the SS, supervise the quality of therapeutic services and provide the official certification to the $\mathrm{ThC}$ that fulfill regulatory requirements.

The fact that $\mathrm{ThC}$ are implanted in coastal or inland regions, generally premountainous, and have varied and pleasant landscapes, gradually it was created an interaction between the actors of Tourism and Thermalism. Thus, both sectors gain mutual benefits. Private stakeholders directly involved in the relationship between thermalism and tourism are: restaurants, shops, transport, banking, insurance, casinos, parks of exhibitions, cinemas, theaters and museums.

The tour guides play an important role in the French thermal regions. Visits and conferences, organized under the aegis of the local tourism organization, are not limited to natural and cultural domain but include, in their programs, visits closely linked to the history and evolution of the local thermalism, as well as the thermal architectural heritage.

Indeed, the buildings of several French ThC date back to the early twentieth century and are masterpieces of Art Nouveau and Art Deco. Thus, the curist of the morning becomes a tourist in the afternoon. In this way, the curist/tourist, having pleasant experiences and being in love with the region, will become an assiduous curist and he will become loyal curist to a particular ThC (Anido Freire, 2012a).

\section{Discussion}

For a better diagnosis of the current situation of French Thermalism and be able to better plan its future evolution, we developed the following SWOT matrix. Some of the already deduced weaknesses of this SWOT analysis have had a response from ThC. However, there are other threats that require more creative effort of ThC to overcome them.

- Although the average cost of a thermal cure is high (between 1000 and $1200 €$ ) and that the current global crisis is aggravated since 2007, the activity of the French ThC knew an increasing number of curists and therefore of its turnover. In 2009 the turnover of the "Chaîne Thermale du Soleil" was $€ 100$ million.

But as prices rise faster and intensely than salaries and pensions, the purchasing power of French people gradually decreases.

To compensate for this loss of purchasing power and not have to give up a thermal cure necessary for good health, curists have decided to save some unnecessary expenses of accommodation in a $3 *$ or $4 *$ hotel, by choosing a much cheaper accommodation (hotels $1 *$ or $2 *$; campsites) but away from ThC. The reaction of the managers of the ThC was immediate: now, they offer to transport freely the curists who are not staying at the $\mathrm{ThC}$, allowing them to receive their cure, and then ensuring their loyalty.

- Moreover, the professionals of thermalism are directly or indirectly confronted to an increased competition created by the multiplication and trivialization of SPA and by the invasion of practices of "low-cost" promotions like "weekend", "last minute", "discovery", etc., in the tourism sector in general (agencies and transportation companies, hotels, restaurants).

Faced with this situation, the heads of $\mathrm{ThC}$ are proposing two solutions:

- the same offers, but at lower price, for the convinced thermalism followers, by reducing costs on most items (accommodation, catering, cost of professional labor), but with the risk of lowering the quality of services,

- and new offers in response to new demands and to conquer new customers, be inspired by the techniques of low-cost, and proposing for example, a "week-end of discovery" of the benefits of thermal waters for wellness, alone, in duo or in family.

- In France, more than $90 \%$ of the turnover of the ThC, is generated by the activities regulated by social organizations. Indeed, providers or operators of French Thermalism depend heavily on social organizations (SS, Mutual Health insurances) responsible for setting the reimbursement rate of thermal treatments to patients.

- The thermal cures represent only $0.15 \%$ of the general expenses of health (CNETh, 2010) and $0.3 \%$ of total reimbursements of the French SS.

However, in the present economic crisis context, there are many people who think that the reimbursement of thermal treatments is unjust when other sectors (rubrics) of Public Health are very deficient (no reimbursement of medicines used to treat many serious diseases, poor reimbursement for eyeglasses, of dental and hearing prosthesis). In late 2012, the Ministry of Public Health think renegotiate the percentage of participation in the 
cost of thermal cures perhaps by reducing it by half. In this case, the number of curists would decrease in France. We believe that the SS should keep in mind that thermal treatments constitute cost savings in consultations, medications and additional treatments of pathologies often successfully treated in the ThC (CNETh, 2006a, 2006c, 2012).

Table 1. SWOT matrix of French Thermalism

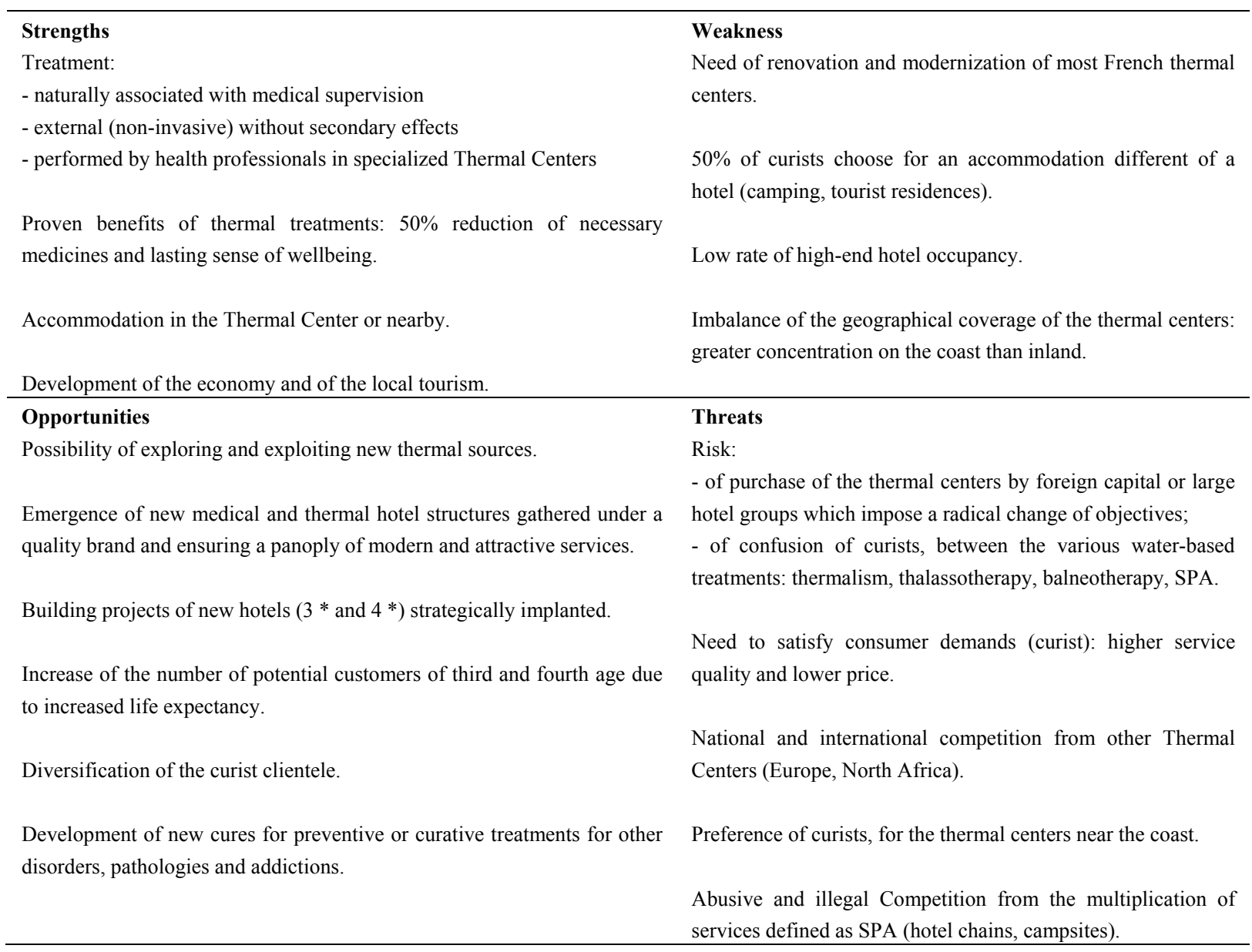

\section{Proposals for Possible Strategic Guidelines}

Given the above analysis we can establish the following strategic proposals for maintenance and future development of French Thermalism.

(a) Develop "classical / traditional" thermalism (thermal cure with financial participation by the SS) by:

- medical diversification using thermal waters (Ebrard, 2007) for example to treat fibromyalgia, Altzeimer disease, Parkinson's disease, cerebrovascular accident (CVA), multiple sclerosis (MS), traumatic and post CVA rehabilitation, treatment of various disabling sequelae, treatment of different mental disorders (Dubois, Boulangé \& Lôo, 2000);

- stricter European regulations on the quality of thermal services and facilities.

(b) Develop a luxury thermalism and attract foreign and European curists with high purchasing power.

(c) Reintroduce the education and specialization of Thermal, Hydrological and Climatic Medicine in the French Faculties of Medicine.

(d) Harmonize the content of programs with a view to obtaining a European Diploma of Technical Thermal Therapist would allow greater mobility of qualified personnel within the EU (European proposal, 2010a, 2010b).

(e) Increase and diversify the range of infrastructure, equipment and service offerings and related tourism activities for curists and accompanying persons, to attract new clients/patients and develop loyalty (Tabone, Dunand, Auzanneau \& Lamerain, 2009) of the regular curists. 
(f) Promote a mix marketing oriented toward intergenerational thermalism (Roques, 2003) for hereditary diseases or familial predisposition factors, which may be accompanied by a development of tourism related activities for the benefit of the whole family.

(g) Improve techniques and communication strategies:

- to allow the Thermalism to do not be considered as a "treatment exclusively for the elderly."

- to give a more adequate, modern and real image of traditional thermal techniques whose effectiveness is demonstrated by numerous scientific publications (Queneau et al., 2001; Roques-Latrille, 2006).

(h) Encourage research on the therapeutic techniques used by the thermalism and the benefits to individual health and Public Health, conducted by university institutions related to thermalism and official agencies (Public Health Ministry and Ministry of Environment and Spatial Territory).

(i) Develop and encourage technical innovations of water treatment, preparation and packing of mud, water transportation, pipelines, heating from geothermal energy, development of renewable energies (solar, geothermal), respecting the principles of sustainable development of each thermal region.

(j) Because the French ThC accommodate 500000 curists per year, the exploitation of natural sources of French thermal waters are optimized to the maximum but only for 9.5 months. Diversification of offers (Salles, 2003) would ensure full employment rate of ThC throughout the year, including the winter quarter.

(k) One should not forget the respect of the environment and the planet, in a strict context of ethics and sustainable development. The extraction and professional use of thermal waters should be equivalent to the capacity of hydro-system renewal to prevent aquifer reservoir depletion.

(l) The Thermalism sector in full activity is a powerful ally of ecology, because imposes the respect of the principles of sustainable development since it prevents that, in a security perimeter, fertilizers, insecticides, industrial pesticides that irreversibly contaminate the ground water and ancient springs, could be used in an improper and unnecessary way.

\section{Conclusions}

- With the present extension of life expectancy (the French population is gaining a year of life every four years) and active aging (OMS/WHO, 2002) and growing longevity (in France, it is expected not only an increase in the total number of centenarians, but also a development of a greater longevity, nowadays with an average of 110 years), thermal therapeutic needs (demand) will increase in the coming decades.

Therefore, the offers should follow the same growth, if the ThC intend to successfully respond to such demands (Ebrard, 2007). Concomitantly, the number of trained, qualified and then contracted geriatricians in the ThC should also increase.

- It is expected that in the coming years, there is a greater number of thermal centers specializing in child and adolescent pathologies (Armand et al., 1991), and also in some of the so-called "orphan diseases" that are accompanied by satellites disabling disorders, often extremely painful, for which laboratories do not want to spend money because they know in advance that there will be "no profitable".

- Despite the positive results, French ThC should continue to consider the expectations of customers and their evolution over time if they want to keep curists and win new customers. It also should not lose sight their diversification: besides subsidized cures and free cures, they will need to promote offers of short programs of prevention (obesity, diabetes, smoking, alcoholism, drug addiction, dehydration, loss of muscle mass and autonomy drive, memory loss and dependency of the elderly).

Taking into account the foregoing, we believe that the French thermalism has conditions to develop further in the short, medium and long term given the current policy of renewal and development of new ThC, the constant commitment of specialization of thermal physicians, therapist technicians, as well as links maintenance and development with the various stakeholders of tourism sector.

\section{References}

Anido Freire, N. (2012a). Actualidad del Turismo Termal y del Termalismo en Francia. In La Diferenciación y segmentación de los mercados en los destinos turísticos (pp. 83-108). Valencia, España: ed. Tirant Lo Blanch.

Anido Freire, N. (2012b). The Emergent Medical Tourism: Advantages and Disadvantages of the Medical Treatment Abroad. International Business Research, 5(2), 41-50. 
ANMThC, Association Nationale des Maires de Communes Thermales. (2010). Retombées du thermalisme sur l'économie et l'emploi, p. 26, Salon des Thermalies, Paris.

Armand, B., Armenier, F., Auge, J. M., Casedevant, B., Darrouzet, J. M., Delaire, P. L. J., et al. (1991). Mieux connaître les Cures Thermales chez l'Enfant (p. 126). Paris: Expansion Scientifique Française.

CNETh, Conseil National des Exploitants Thermaux. (2006a). Enquête curistes 2006 (TNS, SOFRES Healthcare), Le Thermalisme: un enjeu médical, p. 28. Retrieved from http://www.medecinethermale.fr/publications

CNETh, Conseil National des Exploitants Thermaux. (2006b). Enquête curistes 2006 (TNS, SOFRES Healthcare), Le Thermalisme: un enjeu économique, p. 21. Retrieved from http://www.medecinethermale.fr/publications

CNETh, Conseil National des Exploitants Thermaux. (2006c). Enquête curistes 2006 (TNS, SOFRES Healthcare), Synthèse, p. 5. Retrieved from http://www.medecinethermale.fr/publications

CNETh, Conseil National des Exploitants Thermaux. (2008). Thermalisme et santé publique: vers de nouvelles convergences Livre Blanc, p. 76, édité par le Conseil National des Exploitants Thermaux (CNETh), Paris, Février 2008. Retrieved from http://www.medecinethermale.fr/publications

CNETh, Conseil National des Exploitants Thermaux. (2010a). Le guide du thermalisme (36th ed., p. 266). Groupe Impact Médecine, Paris. Retrieved from http://www.medecinethermale.fr/publications

CNETh, Conseil National des Exploitants Thermaux. (2010b). Analyse de la fréquentation médicale des établissements thermaux par orientation thérapeutique. Retrieved from http://www.france-thermale.org/chiffre.php3?txt=freq, Thermes et cures thermales en France - Le Site Officiel.

CNETh, Conseil National des Exploitants Thermaux. (2010c). La médecine thermale, traitements et tarifs de cure conventionnels. Retrieved from http://www.france-thermale.org/medecine-thermale.php3

CNETh, Conseil National des Exploitants Thermaux. (2012). Les stations thermales françaises. La médecine thermale, efficace pour longtemps, p. 28, Paris.

Delomenie, P. (2000). IGAS, Rapport sur le thermalisme français. Rapport n²000119, octobre 2000, La Documentation Française, p. 63, Paris.

Direction du Tourisme. (2010). Tourisme de santé et de bien-être, Tourisme de A à Z - Direction du Tourisme, p. 10, Paris.

Dubois, O., Boulangé, M., \& Lôo, H. (2000). Thermalisme, hydrothérapie et psychiatrie. Masson, Paris.

Duhot, E., \& Fontan, M. (1963). Le thermalisme, Que sais-je? PUF, p. 106, Paris.

Ébrard, J. C. (2007). Interview Avenir du Thermalisme: Priorité à la diversification médicale. Revue Espace, 244, 9-11.

European proposal. (2010a). Synthèse européenne des états de lieux des besoins de professionnalisation des agents de soin thermal en Bulgarie. France et Roumanie (Commission Européenne, Therm, projet $\mathrm{n}^{\circ}$ 134098-LLP-2007-BG-LMP), p. 64. Retrieved from www.projettherm.eu/download/fr/1_EU_fr.pdf

European proposal. (2010b). États de lieux des besoins de professionnalisation des agents de soin thermal en France (Commission Européenne, Therm, projet $n^{\circ}$ 134098-LLP-2007-BG-LMP), p. 50. Retrieved from www.projettherm.eu/download/fr/1_FR_fr.pdf

Fenina, A., Le Garrec, M. A., \& Koubi, M. (2010a). Comptes nationaux de la santé 2009. (document de travail) $\mathrm{n}^{\circ} 149$, septembre 2010, p. 24 DREES (Direction de la recherche, des études, de l'évaluation et des statistiques). Retrieved from www.sante-sports.gouv.fr/IMG/pdf/seriestat149_partie1.pdf

Fenina, A., Le Garrec, M. A., \& Koubi, M. (2010b). Comptes nationaux de la santé 2009. Notes, p. 100, Paris. Retrieved from http://www.drees.sante.gouv.fr/comptes-nationaux-de-la-sante-2009,7120.html

Jacob, J. C. (2010). Thermalisme et Thalassothérapie (p. 13). Tourisme de A à Z, Direction du Tourisme, Paris. Retrieved http://www.veilleinfotourisme.fr/servlet/com.univ.collaboratif.utils.LectureFichiergw?ID_FICHIER=13336 91711470 .

Jaltel, M. (2003). La santé par les eaux: 2000 ans de thermalisme (p. 176). L'instant durable (Ed.), Clermont-Ferrand, France. 
Jaltel, M. (2011). Thermalisme et bien-être: de la remise en forme aux soins curatifs (p. 285). Paris: Chiron (ed.).

Jamot, Ch. (1988). Thermalisme et villes thermales en France (p. 539). Presses Universitaires Blaise Pascal, Clermont-Ferrand, France.

Mosset, Ph., \& Victor, F. (2011). La diversification des activités des stations thermales, Conseil National du Tourisme, Ministère de l'Économie, des Finances et de l'Industrie, p. 74, Paris. Retrieved from www.tourisme.gouv.fr/cnt/publications/rapport-stat-therm.pdf

OMS/WHO. (2002). Vieillir en restant actif, Cadre d'orientation, OMS, p. 60. Retrieved from WHO_NMH_NPH_02.8_fre.pdf

Queneau, P., Boulangé, M., Françon, A., Graber-Duvernay, B., Laroche, C., Oudot, J., et al. (2001). Médecine thermale. Faits et preuves. Paris: Masson.

Roques, Ch. F. (2003). Thermalisme sanitaire et thermalisme social. La Presse Thermale et Climatique, 140, 15-19.

Roques-Latrille, C. F. (2006). Modernité du thermalisme. In Florilège thermal. Les 150 ans de la Société (pp. 5-8). La Presse Thermale et Climatique (ed.), Société Française d'Hydrologie et de Climatologie Médicales, Paris.

Salles, J. Ch. (2003). Comment rendre une segmentation opérationnelle? De la description à l'explication des comportements de consommation. Décisions Marketing, 32, 45-53.

SNMTh, Syndicat National des Médecins Thermaux. (2007). Guía de buenas prácticas termales. Anales de Hidrología Médica, 2, 95-150.

Tabone, W., Dunand, C., Auzanneau, N., \& Lamerain, E. (2009). Les curistes s'expriment sur la cure thermale: données d'exploitation d'une enquête par questionnaire effectuée à partir de la réponse de 112419 curistes. La Presse Thermale et Climatique, 146, 75-83.

Weisz, G. (2002). Le thermalisme en France au XXè siècle. Medecine/Sciences (EDP Sciences), 18(1), 101-108. 